\title{
Abuse of Dominance in the Case-law of the Hungarian Competition Authority - a Historical Overview*
}

\author{
by
}

\author{
Ákos Réger** and András M. Horváth***
}

\section{CONTENTS}

I. Introduction

II. Development of abuse of dominant cases in the case-law of the HCA

III. High number of exploitative cases in the 2000s

IV. General principles followed by the HCA in exclusionary cases

1. Prohibition decisions

1.1. Municipalities

1.2. Telecom

1.3. Energy

1.4. Transport

1.5. Banking

2. Commitment decisions

3. Termination decisions

V. Cost allocation in dominance cases

1. Exploitative (excessive pricing) cases

2. Exclusionary (foreclosure) cases

* This paper expresses the personal and independent opinions of the authors without any bias and without any interference by any third party. The earlier version of this paper was presented at the $6^{\text {th }}$ Zagreb Competition Law and Policy Conference in Memory of Dr. Vedran Śoljan, Challenges to the Enforcement of Competition Rules in Central and Eastern Europe, 12-13 December 2019, Zagreb, Croatia

** Managing Economist, Allegro Consulting; e-mail: akos.reger@allegro-consulting.com; ORCID: 0000-0003-1785-1242

*** Senior associate, Hegymegi-Barakonyi and Partner Baker \& McKenzie Attorneys-atLaw; e-mail: andras.horvath@bakermckenzie.com

Article received: 2 February 2020, accepted: 24 July 2020. 
VI. Significant market power of retailers

1. Regulatory background

2. Case-law

VII. Conclusions

\section{Abstract}

This paper provides a historical overview of the case-law and practices applied by the Hungarian Competition Authority (HCA) in abuse of dominance cases. The paper is co-written by practitioners of complementing antitrust fields, which ensures that both legal and economic considerations are explored. The paper identifies the unique characteristics of Hungarian legislation and case-law and critically evaluates them in light of EU competition law and economics principles. We analyse (i) the reasons for the high number of exploitative cases before 2010, (ii) the general principles applied by the HCA in exclusionary cases, (iii) the cost allocation assessments in dominance cases, and (iv) the issue of significant market power of retailers. The general starting point is that, judging by the number of dominance investigations, there is less antitrust enforcement by the HCA in recent years. However, the article concludes that less enforcement does not mean weaker enforcement. In fact, the quality of dominance cases, considering both legal and economic aspects, has increased over time. This tendency has also led to higher legal certainty in Hungary, which is beneficial for market players. Stronger criticism is only formulated against the concept of significant market power of retailers.

\section{Résumé}

Cet article donne un aperçu historique de la jurisprudence et des méthodes appliquées par l'Autorité hongroise de la concurrence (HCA) dans les affaires d'abus de position dominante. Le document est co-rédigé par des praticiens des domaines complémentaires de l'antitrust, ce qui garantit que les aspects tant juridiques qu'économiques sont explorés. Le document identifie les caractéristiques uniques de la législation et de la jurisprudence hongroises et évalue de manière critique à la lumière des principes du droit de la concurrence et de l'économie de l'UE. Les auteurs analysent (i) les raisons du nombre élevé d'affaires d'exploitation avant 2010, (ii) les principes généraux appliqués par la HCA dans les affaires d'exclusion, (iii) les évaluations de la répartition des coûts dans les affaires de position dominante et (iv) la question du pouvoir de marché significatif des distributeurs. Le point de départ général est que l'application des règles antitrust par la HCA a été plus limitée ces dernières années, à en juger par le nombre d'enquêtes sur les positions dominantes. Toutefois, l'article conclut qu'une application réduite n'est pas synonyme d'une application plus faible. En fait, la qualité des affaires de position dominante, tant du point de vue juridique qu'économique, a augmenté au fil du temps. Cette tendance a également conduit à une plus grande clarté 
juridique en Hongrie, ce qui est bénéfique pour les acteurs du marché. Larticle formule des critiques plus sévères à l'encontre du concept de pouvoir de marché significatif des distributeurs.

Key words: abuse of dominance; competition law; historical overview.

JEL: D42, D43, K21, L12, L13, L41

\section{Introduction}

Our paper provides an overview of the case-law and the practices applied by the Hungarian Competition Authority (hereinafter, HCA) in abuse of dominance cases from the 2000 s to date. ${ }^{1}$ The paper focuses on the evolution of the case-law comparing to EU standards and investigates the application of legal and economic principles by the HCA in dominance cases. It also identifies and critically evaluates the features that are different from mainstream legal and economic thinking applied in the antitrust cases of the European Commission (hereinafter, EC).

In this paper, we carry out a detailed analysis of exploitative and exclusionary cases of the HCA. In particular, we analyse the unique characteristics identified in the case-law: (i) the reasons for the high number of exploitative cases before 2010, (ii) the general principles applied by the HCA in exclusionary cases, (iii) the cost allocation assessments in dominance cases, and (iv) the issues with the concept of significant market power of retailers.

\section{Development of abuse of dominance cases in the case-law of the HCA}

The Hungarian Competition Act ${ }^{2}$ prohibits dominant companies applying anti-competitive practices. It is prohibited, inter alia, to apply unfair prices or other unfair trading practices, ${ }^{3}$ to unjustifiably refuse to deal with business partners, ${ }^{4}$ to discriminate - without justification - between trading partners

\footnotetext{
1 Previous legal work undertaken in this field include Nagy (2013), Szilágyi and Tóth (2013). Economic papers related to the field include Infrapont (2007), Bodócsi (2009), and in particular Győrfi (2016).

2 Act LVII of 1996 on the Prohibition of Unfair and Restrictive Market Practices.

${ }^{3}$ Section 21 (a) of the Competition Act.

4 Ibidem, Section 21 (c).
} 
of equivalent transactions, ${ }^{5}$ to set prices too low so that they are capable of excluding rivals or hinder their market expansion (unless it is based on the greater efficiency level of the dominant company $)^{6}$ and to create, without justification, disadvantageous market conditions that may harm competitors. ${ }^{7}$ The principles outlined in the Competition Act are in line with the EU law. Although the Competition Act contains a more comprehensive list of prohibited abusive actions than Article 102 TFEU, most of these provisions can be linked to the text of Article $102 \mathrm{TFEU}^{8}$, or at least to the corresponding sections of the EC Guidance Paper on exclusionary conducts. ${ }^{9}$

The prohibition of abuse of dominance is regulated elsewhere too. First and foremost, since 1 January 2012, when the new Hungarian constitution ${ }^{10}$ entered into force, the prohibition has an explicit constitutional basis. Article M) (2) of the Fundamental Law of Hungary states that Hungary shall act against the abuse of a dominant economic position. The legislator wanted to emphasize that competition can be restricted based on public interests, for which the prohibition of abuse of dominance is a good example, because it covers conduct that can be otherwise carried out by non-dominant companies (Cserny and Téglási, 2015, p. 9). Since 15 March 2014, when the new Hungarian Civil Code ${ }^{11}$ entered into force, the prohibition has an explicit civil law consequence. Section 6:72 of the Civil Code states that the court can enforce contracting obligations against a party that, by abusing its dominant position, refuses to conclude or maintain the contract without justification. In the absence of case-law based on this rule, it is unclear if abuse of dominance has to be established first by the HCA, before the rule can be invoked before a court.

The anti-competitive practices related to Section 21 of the Competition Act and Article 102 TFEU can be broadly categorized as either (i) exploitative conducts or (ii) exclusionary behaviour. In exploitative conduct cases the dominant company abuses its market power to the direct detriment of consumers by, for example, applying monopoly pricing or enforcing unfair trading conditions. Anti-

5 Ibidem, Section 21 (g).

${ }^{6}$ Ibidem, Section 21 (h).

7 Ibidem, Section 21 (j).

8 Sections 21 (a), (d) and (j) can be linked to Article 102 TFEU (a); Sections 21 (b) and (e) to Article 102 TFEU (b); Section 21 (g) to Article 102 TFEU (c); Section 21 (f) to Article 102 TFEU (d).

${ }^{9}$ Communication from the Commission - Guidance on the Commission's enforcement priorities in applying Article 82 of the EC Treaty to abusive exclusionary conduct by dominant undertakings, 2009/C 45/02. Section 21 (c) of the Competition Act can be linked to Section 75-79 of the Guidance Paper; Section 21 (h) to Sections 23-27 and 63-73 of the Guidance Paper; Section 21 (i) to Sections 16-17 and 68 of the Guidance Paper.

${ }_{10}$ Fundamental Law of Hungary (25 April 2011).

11 Act V of 2013 on the Civil Code. 
competitive exclusionary conducts are also detrimental to consumers, but they relate to the dominant company's ability and objective of excluding rivals from the market (refusal to deal, predatory pricing, margin squeeze, etc.).

The distinction and the different treatment of exploitative and exclusionary practices can be traced back in the case-law of the HCA to the 1990s. However, in the past the HCA placed more emphasis on exploitative cases and put less effort to capture anti-competitive exclusionary conducts. This may stem from the characteristics of the Hungarian market, but may have also been the reflection of a different approach followed by the HCA in comparison to authorities in other European countries. Also, while until the end of the 2000s the HCA used their investigative power to pursue dominance cases more frequently, in the last decade we observe a significant decline in the total number of dominance cases concluded.

The figure below illustrates these points. Until 2008, up to 20-30 dominance investigations were concluded by the HCA each year. We can also observe that the number of exploitative cases exceeded the number of exclusionary cases (in total). In contrast, the number of dominance cases closed has not exceeded 10 per year since 2011 (less than 5 per year since 2015). This trend may indicate a shift in the attitude of the HCA towards dominance cases, especially with respect to exploitative conducts.

Figure 1. Number of abuse of dominance cases closed by the HCA (2003-2019)

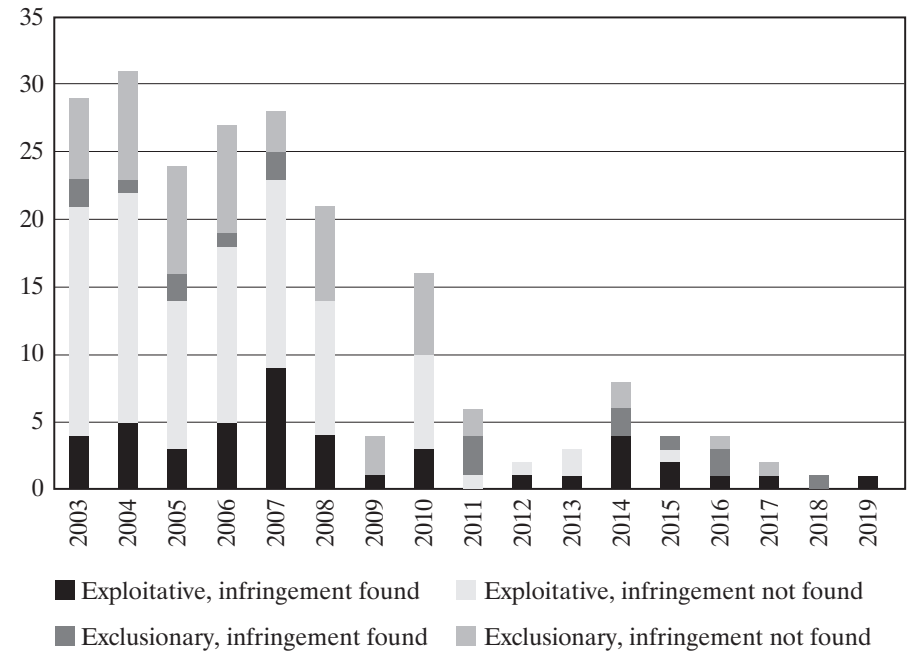

Source: HCA yearly reports to the Parliament, HCA case decisions database. Prohibition and commitment decisions are both counted as infringements. Investigations of exploitative behaviour include buyer-side dominance cases. Follow-up investigations of past decisions are not counted separately. 


\section{High number of exploitative cases in the 2000s}

Figure 1 indicates that a relatively high number of exploitative cases was investigated by the HCA pre-2010, whereas the post-2010 era saw less of such cases. Our research identified two main reasons for this trend:

1. Many companies (especially telecommunication services providers, utility firms and banks) were fined for applying unfair conditions vis-à-vis their consumers; this was a less frequent reason to open an investigation in recent years.

2. The conditions to prove excessive pricing (part of exploitative abuses) used to be less strict than in more recent years.

The first reason is likely to be related to the aftermath of the transition of the country into a market economy. This had an effect in those markets where traditionally there was a single service provider (incumbent) but, even after privatization, the number of competitors was limited and/or the level of market regulation was insufficient: telecommunications markets, utilities markets. For example, Magyar Telekom and Invitel, the two incumbent telecommunication service providers, were fined multiple times because they applied unfair contracting terms in their relationship with consumers. ${ }^{12}$ Other telecommunication companies were also often investigated and fined for unfair trading practices. ${ }^{13} \mathrm{We}$ observe the same tendency, to some extent, in the utilities markets. ${ }^{14}$ Furthermore, despite the relatively high number of banks active in Hungary, they were also often investigated for unfair trading practices (the reason may be the strong market leading position of the incumbent bank OTP)..$^{15}$ These latter cases are assumed to be related to the sectorial inquiry in the financial sector published by the HCA in $2005^{16}$, where the HCA revealed issues related to the high administration fees applied by banks, in particular in connection to real estate loans.

We agree that applying unfair trading conditions is a serious issue that should be dealt with. However, some of these decisions contain features that go beyond the market monitoring function of the HCA. In $U P C^{17}$, the HCA investigated, amongst others, whether the methodology applied in

12 Matáv (Vj-82/2000, Vj-10/2001, Vj-11/2002), MATÁVkábelTV (Vj-97/2001), Invitel (Vj-121/2003), T-Mobile (Vj-82/2004), Magyar Telekom (Vj-8/2006), Invitel (Vj-9/2006).

13 UPC (Vj-18/2002), Egyesült Magyar Kábeltelevízió (Vj-88/2003, Vj-42/2003), FiberNet (Vj-50/2004), Vodafone (Vj-80/2004), Monor Telefon (Vj-10/2006).

14 E.g. Prímagáz (Vj-147/2003), E.ON (Vj-66/2005), TIGÁZ (Vj-116/2005).

15 OTP (Vj-41/2006, Vj-16/2011), K\&H (Vj-16/2008), CIB (VJ-181/2007).

16 A Gazdasági Versenyhivatal Jelentése a Jelzáloghitelezés Tárgyában Lefolytatott Ágazati Vizsgálatról (available in Hungarian only: https://bit.ly/37Ej2nw).

17 Case No. Vj-18/2002. 
the composition of television packages (that is, how many and what channels are bundled in a package) was anti-competitive. ${ }^{18}$ The HCA identified issues with certain business practices of UPC as the cable company made certain low-cost but highly preferred tv-channels available in more expensive packages only. ${ }^{19}$ Therefore, the HCA obliged UPC to survey consumer preferences before deciding on tv-packages. The HCA went further and suggested for the company to set up a reasonably priced basic package (including the most preferred tv-channels). ${ }^{20}$ Similar considerations were put forward in FiberNet, ${ }^{21}$ where the HCA even suggested that FiberNet should attempt to increase the response rate of consumer surveys, by covering the costs of those consumers that actively respond. ${ }^{22}$ These examples show that the HCA sometimes stepped over its responsibilities as a monitoring agency, into the role of a regulatory body. ${ }^{23}$

The second reason for the high number of exploitative cases pre-2010 is related to the meagre theories of harm applied by the HCA in excessive pricing cases. Excessive pricing investigations form a distinctive group within exploitative cases, where the authority is concerned with anti-competitively high margins of the dominant companies that manifest in excessive (noncompetitive) prices. The number of excessive pricing cases within exploitative abuses was surprisingly high in the pre-2010 era, and a significant number of them were concluded with fines or commitments (though not all), mainly related to the telecommunication sector. ${ }^{24}$

An interesting characteristic of these cases (and several others ${ }^{25}$ ) was that the HCA mixed the cost-based approach with a naïve interpretation of the excessive nature of prices when they compared prices to the rate of inflation. In all these cases, the HCA intervened if the price increases of products or

18 UPC was found dominant.

19 Ibidem, para. 103.

20 Ibidem, para. 89.

21 Case No. Vj-50/2004.

22 Ibidem, para. 45. What exactly the HCA meant about covering these costs is not discussed in the decision.

${ }^{23}$ Győrfi (2016) demonstrates more generally that the HCA often stepped into the shoes of a sector regulator.

${ }^{24}$ Based on the GVH's own figures published in the OECD Policy Roundtables (see fn 26, p 255) more than 10 cases were investigated between 2003 and 2006 each year, and in 16 cases firms were fined or obliged to accept commitments between 2003 and 2010. Kábel Televízió Szolgáltató (Vj-48/2002), ViDaNet (Vj-14/2003), Kábelszat-Balatonfüred (Vj-93/2003), UPC (Vj-18/2002, Vj-44/2003, Vj-5/2005), Zelka (Vj-31/2002), FiberNet (Vj-5/2005, Vj-50/2004, Vj-3/2005), PR-Telecom (Vj-98/2005), KábelszatNet (Vj-23/2006), T-Kábel (Vj-25/2006), FiberNet (Vj-37/2002), Antenna Hungária (Vj-45/2003), ViDaNet (Vj-14/2003), Dual-Plus (Vj-48/2005).

25 Dunakanyar Holding (Vj-95/2002), Zalaegerszegi Elektromos Karbantartó (Vj-83/2003), Fövárosi Gázmüvek (Vj-31/2005). 
services (provided by a dominant company) were significantly higher than the rate of inflation, which was used as a benchmark for cost increases. ${ }^{26}$ If the investigated firms did not manage to explain these price rises with legitimate cost increases or investments, which they often could not, then the above-inflation price increase was deemed to be anti-competitive (for further details on the methodology that the HCA applied in these cases see Toth, A. (2008)). This approach placed substantial burdens on the companies under investigation as they had to prove, with detailed calculations, that their price increases were in line with their cost increases. ${ }^{27}$

For example, in Kábelszat-Balatonfüred, the HCA held that the cable provider increased their prices by $14.6 \%$ on average which exceeded the 2002 inflation rate $(5.3 \%){ }^{28}$ The HCA also claimed that the profit margin of $35.4 \%$ is significantly above the risk-free interest rate $(10 \%)$ and the maximum $5 \%$ market-specific risk premium. ${ }^{29}$ The HCA, therefore, fined KábelszatBalatonfüred for excessive pricing. In FiberNet II, the HCA found that from 2004 to 2005 average prices were increased by $19 \%$, which exceeded the 2004 inflation rate of $6.8 \%{ }^{30}$, but they did not find the yearly profit rate of $9-12 \%$ to be above the expected risk-adjusted return in the telecommunications market. ${ }^{31}$ Hence, the HCA did not find the price increase of FiberNet excessive.

In our view, the HCA's approach applied in excessive pricing cases throughout the 2000s, of comparing the price increases with inflation rates as a cost benchmark, was wrong. ${ }^{32}$ We are unaware of any economics textbooks in which such an approach is suggested. It is also at odds with the perspectives of competition law as it is based on the principles of microeconomics, whereas inflation is a concept related to macroeconomics. After all, one cannot expect costs and prices to move to the same (not even to a similar) extent across markets, which is exactly what the HCA's inflation rate-based approach suggested. Suppose, for example, that demand for certain products or services is increasing. One would expect prices to rise in reaction to higher consumer demand - this is not an anti-competitive action and prices can easily increase more than general inflation.

We are also unaware of any excessive pricing cases in the EU that explicitly applied the inflation rate as a benchmark to cost increases. In Russia, the Federal Antimonopoly Service (hereinafter; FAS) pursued an excessive pricing case in

26 OECD Policy Roundtables, Excessive Prices, DAF/COMP(2011)18, 07-Feb-2012, p. 259, fn 15 .

27 Whereas we think that the burden of proof, in these cases, should lie with the authorities.

28 Case No. Vj-93/2003, para. 36.

${ }^{29}$ Ibidem, para. 38.

30 Case No. Vj-5/2005, para. 73.

31 Ibidem, para. 76-77.

32 Contrary to our view, Bodócsi (2009) does not find this approach problematic. 
the petroleum products market where consumer price inflation was compared to price changes of producers but the FAS considered other factors as well (for example, changes in demand). ${ }^{33}$ The Turkish competition authority also used an inflation benchmark in deciding to stop monitoring the thermal energy market. ${ }^{34}$ However, these are exceptional cases and did not take place within the EU.

In any case, from 2006 we did not find excessive pricing cases of the HCA applying an inflation-based analysis. The HCA itself seemed to have admitted that their approach was overly simplistic (Tóth, A., 2008). In 2008, in an investigation against two electricity providers, ${ }^{35}$ the HCA went further and explained that the existence of excessive prices can only be proved in exceptional cases. This is more in line with economic theory ${ }^{36}$, and the above statements of the HCA may have contributed to the decrease of excessive pricing cases in later years. Győrfi (2016) investigated the excessive pricing cases of the HCA, not related to the telecommunications markets, and found that only a few of these were infringement decisions. Also, some of these infringement cases did not end up with antitrust fines (commitments only), reflecting the general standpoint that authorities must proceed with caution in excessive pricing cases (Győrfi, 2006, p. 61). Importantly, Tóth, A. (2008) points out that many of the exploitative cases were not pursued or were suspended by the authority because it was not in the public interest to carry out a full investigation. Examples of cases where lack of public interest was considered included instances when: the investigated market was small; consumers were only indirectly affected; the market was regulated; the case would have meant an inefficient utilization of human resources of the authority.

\section{General principles followed by the HCA in exclusionary cases}

Exclusionary cases can be challenging for authorities, but it is important that an appropriate assessment is carried out as, in the long term, exclusionary conducts often cause larger damage to consumer welfare than exploitative cases (Tóth, 2014, p. 246). However, it is the competitive process that should

33 Supra note 26, para. 359.

34 Ibidem, para. 426.

35 Dél-magyarországi Áramszolgáltató Zrt. and DÉMÁSZ Hálózati Elosztó Kft. (Vj-126/2007).

36 Economists generally agree that excessive pricing cases should only be pursued by competition authorities in exceptional circumstances and, if prices are excessive and there are no other remedies available like market entry, a regulator should intervene, not the competition authority (see e.g. Motta, 2009, p. 69-70. A more recent paper on this topic is De Coninck, 2018). 
be protected by the authorities and not individual competitors. The key idea is that a competitor should not be kept in the market if the market functions more efficiently without it.

Exclusionary practices are considered more harmful, as they directly decrease the intensity of competition and even jeopardize competition itself (Juhász, Ruszthyné Juhász and Tóth, 2014, p. 283). Nevertheless, it was already suggested in 2013 that combating abuses was not a priority for the HCA. Exclusionary abuses, in particular, are sometimes not prosecuted, because harm to actual or potential competitors and business partners does not qualify as abuse in itself (Nagy, 2013, p. 54-55). Figure 1 indicates that the number of exclusionary cases (shown in orange) is notably lower than the number of exploitative cases. In particular, from 2003 to date, we count merely 17 exclusionary conduct cases closed by the HCA by finding an infringement, or not finding an infringement only due to the commitments of the undertakings. ${ }^{37}$ The number of exclusionary cases without finding an infringement is higher, although we identified only 6 such cases since 2011.38 These can be explained either by the lack of anti-competitive exclusionary conducts in Hungary, or by the realisation that exclusionary cases are relatively difficult to capture for the HCA. Naturally, we can only investigate the latter.

\section{Prohibition decisions}

Prohibition decisions can be categorized according to sectors: (i) cases regarding municipality companies, (ii) telecom cases, (iii) energy cases, (iv) transport case, and (v) banking cases.

\subsection{Municipalities}

In the Elek Város Önkormányzata case, ${ }^{39}$ the HCA investigated if the decision of a municipality - as the owner of the land, where a cable network was intended to be established - qualified as refusal to deal. As the municipality

37 Elek Város Önkormányzata (VJ-6/2002), MATÁV (Vj-100/2002), Tiszántúli Gázszolgáltató (Vj-155/2002), Magyar Telekom (Vj-66/2004), Anubisz Temetkezés (Vj-118/2004), Magyar Államvasutak (Vj-22/2005), Hungarotel (Vj-69/2005), Gyóri Ipartestület (Vj-44/2007), Tiszántúli Áramhálózat (Vj-74/2008), Invitel (Vj-121/2009), Városüzemeltetó és Fenntartó (Vj-138/2009), MOL (Vj-50/2010) [discussed in detail in Section V.2. below], E.ON (Vj-97/2011), MasterCard (Vj-46/2012), Nielsen (Vj-59/2013), Budapest Airport (Vj-43/2014), Balatoni Hajózás (Vj-14/2015).

38 GYÖR-SZOL (Vj-39/2009), Groupama (Vj-19/2011), Budapest Airport (Vj-95/2011), Magyar Posta (Vj-32/2012) [discussed in detail in Section V.2. below], Sanofi-Aventis (Vj-61/2014), RTL (Vj-49/2015).

39 Case No. VJ-6/2002. 
did not give its consent as the owner to the establishment of a cable network, the building authorities refused to issue a building permit. The HCA found that the decision of the municipality can have market effects and can be investigated under the Competition Act. The HCA found the municipality to be in a dominant position because the land owned by the municipality was considered an essential facility. The HCA also found that the refusal of consent by an owner was an abuse, because (i) it was unjustified, being only motivated by the wish to protect the local cable TV company (also owned by the municipality) from competition, and (ii) it was capable of restrictive effects on competition. The HCA decided not to impose a fine, only to oblige the municipality to start negotiations with the cable TV company. The HCA did not refer to any EU case-law. However, the HCA made two important theoretical observations: (i) dominant undertakings are not expected to conclude contracts causing them economic harm even in case of refusal to deal, ${ }^{40}$ and (ii) the presence of a competitor in the given geographical market is beneficial for consumers.

In the Anubisz Temetkezés case, ${ }^{41}$ the HCA investigated both Mosonmagyaróvár City Cemetery and the Mosonmagyaróvár City Funeral Company (owned by the cemetery). As there was only one cemetery in the city, and the funeral company conducted nearly all funerals, both were found to be dominant. Regarding the conversion of the dominance of the cemetery to the funeral company, the HCA relied on previous case-law. ${ }^{42}$ On the one hand, the HCA found that the setting of the rent for the funeral home by the cemetery qualified as setting unfair prices. Regarding the unfair nature, the HCA relied on the fact that the subsidy provided by the city was disregarded in the fees applied to other funeral companies. ${ }^{43}$ On the other hand, the rent of the funeral home was only partially included in the burial service fee of the funeral company, which qualified as hindering market entry and creating disadvantageous conditions for competitors. ${ }^{44}$ The HCA made no reference to EU case-law but carried out detailed calculations regarding the actual costs of the cemetery and the fee applied by the funeral company. The decision was confirmed in judicial review. 45

40 This reflects the EU-standards set out in Joined Cases C-241/91 P and C-242/91 Radio Telefis Eireann (RTE) and Independent Television Publications (ITP) v Commission (Magill) [1995] ECR I-743.

41 Case No. Vj-118/2004.

42 Gyertyaláng (Vj-108/2001).

43 Case No. Vj-118/2004, para. 29.

44 Idem, para. 38.

45 Judgment of the Metropolitan Court - 3.K.32.672/2005/8. (24 March 2006). 
In the Városüzemeltetó és Fenntartó case, ${ }^{46}$ the HCA investigated the conduct of the Mosonmagyaróvár City Cemetery in connection with the contractual negotiations with an independent funeral company. The HCA examined if the detrimental contractual conditions could qualify as an abuse. However, in the end, the HCA found that the delay in negotiations caused by the cemetery, together with the detrimental conditions (requiring a deposit and request of service in advance) qualified as an abuse. ${ }^{47}$ The HCA made no reference to EU case-law. It was discussed that the court, in its judgment ${ }^{48}$ confirming the HCA decision, considered that the information was provided to the new market entrant either in a flawed or in an overly slow manner, and that was an important factor in the act of delaying negotiations (Szilágyi and Tóth, 2013, p. 189).

\subsection{Telecom}

In the $M A T A V$ case,${ }^{49}$ the HCA investigated if the incumbent telecom company applied margin squeeze in the retail call services market. The allegation was that the undertaking determined the prices for its retail call services, in comparison to the prices of its wholesale connection services, in a way that effectively hindered the market entry of other telecom service providers. The investigation followed the telecommunication market liberalization in 2002. The HCA established that the undertaking had a dominant position in the wholesale market (it owned $79 \%$ of the network). The HCA considered a dominant position in the retail market unnecessary because the undertaking clearly had a strong market position and the margin squeeze aimed either at creating or strengthening this position. The HCA applied the following margin squeeze definition: 'a vertically integrated undertaking, which has a dominant position regarding wholesale services, which are essential for retail services and constitute significant costs thereof, determines its wholesale and retail prices in a way that precludes (similarly) efficient competitors to provide retail services profitably, due to the narrow margins, and thereby forecloses competitors or hinders their entry. ${ }^{50}$ Notably, the HCA's analysis used cost figures of an 'exactly equally efficient competitor'. ${ }^{51}$ The HCA found that due to high wholesale prices, the margins were negative, which always qualifies as margin squeeze. However, the HCA emphasized that margin squeeze is

\footnotetext{
46 Case No. Vj-138/2009.

$47 \mathrm{Vj}-138 / 2009$, para. 95.

48 Judgment of the Metropolitan Court - 2.Kf.649.926/2013/2 (2 May 2013).

49 Case No. Vj-100/2002.

${ }^{50} \mathrm{Vj}-100 / 2002$, para. 94 (translated from Hungarian).

51 Ibidem, para. 109.
} 
possible even in case of a positive margin, but a detailed cost analysis would need to be carried out in such cases. ${ }^{52}$ The HCA did not refer to any EU case-law. Nevertheless, at that time EU case-law on margin squeeze was not fully developed (Valentiny, 2004, p. 39). In any case, the same test used by the HCA was included in paragraph 80 of the EC Guidance Paper on exclusionary conducts. It was suggested that margin squeeze can only be established if the margin is unreasonably low, if the practice lasts for a long period of time, and considerable entry barriers exist (Nagy, 2013, p. 70).

In the Magyar Telekom case, ${ }^{53}$ the HCA investigated again the incumbent telecom company's pricing practices, this time in the interconnectivity market. The subject-matter of the investigation was if the discrimination of on-net and off-net calls regarding the fees applied to partner service provider, as well as the refusal to share the costs of creating interconnectivity links with a partner service provider, qualified as an abuse. While the HCA found that the first conduct could have (potentially) worsened the competitive situation of partner service providers, even though the partner service providers themselves made statements about negligible losses, ${ }^{54}$ the HCA determined the actual loss suffered by the partner service provider (HUF 7 million) as a result of the second conduct (refusal to share the costs of creating interconnectivity links). ${ }^{55}$ Magyar Telekom was found to be dominant in the interconnectivity market, because it had $79 \%$ of the fixed-line retail telephony subscribers, even though, the sectorial regulator did not impose obligations on the incumbent as a service provider with significant market power (its turnover-based market shares did not exceed the threshold of 25\%). ${ }^{56}$ Originally the HCA alleged that Magyar Telekom applied conditions detrimental to competitors. In the end, the HCA found that the enforcement (coercion) of these conditions was not corroborated. However, the prescription of unjustified benefits for Magyar Telekom was manifest. ${ }^{57}$ Regarding the unjustified nature, the HCA relied on the circumstance that there was no difference in the physical content of on-net and off-net calls. The HCA did not refer to any EU case-law. The HCA analysed fees and costs in detail, however, they only applied a simple comparative method. The decision was confirmed in judicial review. ${ }^{58}$

52 Ibidem, para. 129.

${ }^{53}$ Case No. Vj-66/2004.

$54 \mathrm{Vj}-66 / 2004$, para 96.

55 Ibidem, para. 56.

56 Ibidem, para. 116-117.

57 Ibidem, para. 132-133.

58 Judgments of the Metropolitan Court - 2.K.30.093/2006/7 (11 May 2007) and 2.K.32.765/2009/3 (8 January 2010). 
In the Hungarotel case, ${ }^{59}$ the HCA investigated the network access agreements of a telecom company. The HCA established the dominant position of the telecom company in five local markets (with a market share of ca. $75 \%$ ). Interesting to note that the HCA found no substitutability regarding fixed and mobile telephony at the time (2006). ${ }^{60}$ The starting point of the HCA's assessment was that switching is beneficial for consumers. The telecom company enabled the switching of consumers in case of the basic package but not for packages with discounted tariffs, thereby, hindering effective switching. This was demonstrated by an actual low switch rate since the introduction of the tariff. This was considered as hindering market entry and creating disadvantageous conditions for competitors. The HCA rejected the defence of the telecom company, namely that enabling switching in discounted tariff packages would have jeopardized the operation of the company. The HCA also found infringements of Article 102 TFEU, however, the HCA has not referred to EU case-law in its legal assessment.

The Invitel case ${ }^{61}$ was a repeated procedure after the court annulled the decision in the Hungarotel case ( $\mathrm{Vj}-69 / 2005)$ based on insufficient reasoning, inter alia, on the definition of the relevant market. ${ }^{62}$ Most notably, the HCA found that - due to the limited geographical area and the low number of consumers - the trade between Member States is not affected and did not find an infringement of Article 102 TFEU. ${ }^{63}$ Otherwise, the HCA - after collecting additional evidence - re-affirmed its original position on the relevant market, dominance and abuse. The decision - after a prolonged dispute on the amount of the fine - was confirmed in judicial review. ${ }^{64}$

\subsection{Energy}

In the Tiszántúli Gázszolgáltató case, ${ }^{65}$ the $\mathrm{HCA}$ investigated if the biggest natural gas supplier (Tigáz), who was at the same time the exclusive operator of the natural gas network in several regions, hindered market entry. Under the regulatory framework at the time, the local municipalities could engage other natural gas network construction companies. However, Tigáz was

59 Case No. Vj-69/2005.

$60 \mathrm{Vj}-69 / 2005$, para. 97.

61 Case No. Vj-121/2009.

${ }^{62}$ It was emphasized regarding the judicial review of the case that the court, annulling the HCA decision (Judgment of the Metropolitan Court - 2.Kf.649.905/2013/3. (18 February 2015)), refrained from replacing the HCA in carrying out its tasks regarding adequate reasoning (Szilágyi and Tóth, 2013, p. 189.).

$63 \mathrm{Vj}-121 / 2009$, para. 47.

64 Judgment of the Metropolitan Court - 2.Kf.650.095/2014/8 (27 March 2013).

65 Case No. Vj-155/2002. 
empowered to classify these companies. The HCA found that Tigáz had a dominant position on the natural gas network construction market ${ }^{66}$ and considered Tigáz's classification practices an abuse. ${ }^{67}$ The HCA did not refer to any EU case-law and applied a formalistic approach without establishing a test. Important to note that the HCA did not investigate if any construction companies were excluded due to Tigáz's policy.

In the Tiszántúli Áramhálózat case, ${ }^{68}$ the HCA investigated the long-term electricity purchase agreements for public lighting purposes of the regional electricity provider (Titász) and the municipalities. The case was a repeated procedure, after the court found that the HCA's reasoning in the original case (Vj-175/2001) was insufficient regarding the identification of municipalities affected. ${ }^{69}$ Titász applied a clause according to which municipalities were obliged to reimburse the costs of public lighting network development (carried out by Titász) within a short deadline and in a lump sum, if the municipalities purchased electricity from another company. The HCA found that, as a result of its legal monopoly before 2001 regarding both the operation of public lighting network and sale of electricity for public lighting purposes, Titász had strong market positions, qualifying as a dominant company. ${ }^{70}$ The HCA qualified the conduct towards municipalities as an enforcement of detrimental conditions, and towards competitors creating disadvantageous conditions. The HCA did not refer to any EU case-law. The decision was confirmed in judicial review. ${ }^{71}$

\subsection{Transport}

In the Magyar Allamvasutak case, ${ }^{72}$ the HCA investigated practices of Hungarian Railways. Hungarian Railways applied various terms towards its rival railway companies in network access agreements hindering their market entry. The HCA established the dominant position of Hungarian Railways on several markets: (i) access to public tracks, where the Hungarian Railways had a legal monopoly; (ii) access to non-public tracks, because Hungarian Railways owned $71 \%$ of industrial tracks; and (iii) freight forwarding to industrial clients, where Hungarian Railways had high market shares per industrial clients (for example, an exclusive contract with the Hungarian oil

$66 \mathrm{Vj}-155 / 2002$, para. 21.

67 Ibidem, para. 24.

68 Case No. Vj-74/2008.

69 Judgment of the Metropolitan Court of Appeal - 2.Kf.27.329/2007/5 (6 February 2008).

$70 \mathrm{Vj}-74 / 2008$, para. 66.

71 Judgment of the Metropolitan Court - 2.K.31.554/2011/8 (11 January 2012).

72 Case No. Vj-22/2005. 
and gas company). The HCA considered (i) the unjustified duty, of obtaining a bank guarantee, imposed on private railway operators for network access, to be creating disadvantageous conditions for competitors; (ii) the hindrance or delay of access to industrial tracks to be a refusal to deal; and (iii) the conclusion of exclusive agreements with freight forwarders a hindering of market entry. ${ }^{73}$ The HCA also found infringements of Article 102 TFEU regarding the conduct applied after Hungary's accession (1 May 2004). For this reason the HCA relied extensively on EU case-law. ${ }^{74}$ It was emphasized that the gravity of the infringement was influenced by the context of the case: the investigated practices were carried out immediately after the opening up of the market and they were considered to have the potential to hinder the success of market liberalization (Tóth, 2008, p. 19-20). As reported, ${ }^{75}$ on judicial review at first instance, the part of the HCA decision on the unjustified condition of a bank guarantee was quashed, however, on appeal this was reversed. The final and binding judgment ${ }^{76}$, changing the outcome for the second time, sided with the first instance judgment.

\subsection{Banking}

In the MasterCard case, ${ }^{77}$ the HCA investigated if the interchange fee applied by the card company foreclosed the Hungarian upstream market (providing debit cards to issuing banks). The background of the investigation was that the main competitor of MasterCard, namely VISA, was restricted - as a result of a commitment made to the European Commission - in determining its interchange fee freely, and to compete effectively. The HCA found that the market share of MasterCard has increased from $70 \%$ to $85 \%$ in the investigated time period, which suggests a dominant position. ${ }^{78}$ The HCA relied on EU case-law regarding the assessment of dominance. ${ }^{79}$ The HCA also found that

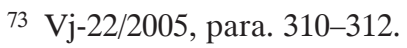

74 Regarding disadvantageous conditions for competitors: COMP/37.685 - GVG/FS (a capacity distributor also operating downstream tends to minimize entry possibilities detrimental for its downstream service). Regarding refusal to deal: Case T-228/96 Irish Sugar Plc. v Commission [ECR 1999, II-02969] (the protection of a dominant company's business interest must be based on economic efficiency). Regarding hindering market entry: COMP/33.133 Solvay (so-called English clauses are capable of hindering entry of competitors at clients of the dominant company).

75 Jogerős ítélet a MÁV ellen, Versenytükör, V. évf. 2. sz., 2009 június, p. 8.

76 Judgment of the Supreme Court - Kfv.II.37.442/2009/12 (10 March 2010).

77 Case No. Vj-46/2012.

$78 \mathrm{Vj}-46 / 2012$, para. 316.

79 In particular, COMP/C-1/36.915 - Deutsche Post AG (level of special responsibility of a dominant company depends on the level of dominance). 
MasterCard abused its dominant position by applying interchange fees that were capable of foreclosing its only competitor from the market. ${ }^{80}$ The entire decision of the HCA was structured in accordance with Chapter III.C of the EC Guidance Paper on exclusionary conducts (price-based exclusionary conduct). Interestingly, the HCA considered it irrelevant whether VISA was an 'as efficient competitor' and whether a cost analysis was necessary. ${ }^{81}$

\section{Commitment decisions}

The characteristic of commitment decisions is that the HCA does not set out in detail the legal assessment of the merits of the case, only the assessment of the proposed commitments.

In the Gyóri Ipartestület case, ${ }^{82}$ the HCA investigated the conduct of the Győr City Industry Association. The HCA alleged that the association, by adopting a limit on taxi stands in the city, both as a horizontal anticompetitive agreement and as unilateral practices of an entity enjoying a legal monopoly, hindered market entry. Also, by applying higher fees to non-member taxi drivers than to its members for accessing taxi stands, the association allegedly discriminated taxi drivers. The association offered commitments to determine a procedure for the issuance of taxi stand permits.

In the $E . O N$ case, ${ }^{83}$ the HCA investigated the market of public lighting again, a few years after the Tiszántúli Aramhálózati case (Vj-74/2008). The HCA alleged that E.ON (through its subsidiaries) set the fee (rent) determined for the use (lease) of the elements of the public lighting networks in a way that foreclosed third parties from the market of operating public lighting networks. E.ON offered commitments to apply a cost-based, fixed fee for the use of public lighting network elements for 3 years.

In the Nielsen case, ${ }^{84}$ the HCA alleged that the viewer ratings service provider foreclosed competitors from the market of analytical software. On the one hand, Nielsen applied a discount to those customers that would purchase viewer ratings data together with the license of its own analytical software. On the other hand, Nielsen also applied contractual (IP) clauses in its contracts with customers, which made it difficult for customers to use a third-party software to analyse the viewer ratings data. The HCA accepted

${ }^{80} \mathrm{Vj}-46 / 2012$, para. 481.

81 To the authors' knowledge, the decision was annulled in judicial review. However, the decision has not yet been published.

82 Case No. Vj-44/2007.

83 Case No. Vj-97/2011.

${ }^{84}$ Case No. Vj-59/2013. 
commitments under which Nielsen was obligated to (i) refrain from a discount in exchange for the buying the license to the software, (ii) sell viewer ratings data without the software, (iii) provide viewer ratings data in a format that enables analysing it with a third party software, (iv) offer technical support for such analysis, and (v) negotiate amendments of existing contracts.

A few years after the HCA had terminated an investigation of the Budapest Airport case (see Section IV.3. below), the HCA proceeded once more against Budapest Airport ${ }^{85}$ on grounds of another discriminatory abuse, ultimately closing this case by way of commitments. During the proceedings, the HCA examined whether the prices and conditions applied by Budapest Airport for drop-offs, as well as short and long term stays at the airport parking premises, could eliminate undertakings providing parking and transfer services in the area of the airport. According to the commitments, Budapest Airport undertook to reduce the prices charged for using parking lots, to provide rebates, and to make possible for rival undertakings to rent bus parking spots under certain conditions.

In the Balatoni Hajózás case, ${ }^{86}$ the HCA investigated the practices of the Balaton Shipping Company. The HCA alleged that the shipping company applied margin squeeze: on the one hand, the company was the owner of all public ports on Lake Balaton, and determined the port usage fee for passenger water transport companies; on the other hand, the shipping company itself carried out downstream (passenger water transport) services. According to the accepted commitments, the shipping company undertook to apply reduced port usage fees for 4 years, unbundled port operational services and passenger water transport services, revised the port usage terms to reflect objective, proportionate, non-discriminatory conditions for downstream competitors.

\section{Termination decisions}

The characteristic of termination decisions is that the HCA only refers to the absence of conclusive evidence, without setting out a detailed legal reasoning.

In the GYÖR-SZOL case, ${ }^{87}$ the HCA investigated two decisions of the Györ City Communal Company: (i) increasing the in-take fee of waste in containers - carried out by third parties - the same level as in-take fee of complex waste - carried out by the communal company itself (margin squeeze), and (ii) discriminating own and third party transports regarding the opening hours.

\footnotetext{
85 Case No. Vj-43/2014.

86 Case No. Vj-14/2015.

87 Case No. Vj-39/2009.
} 
The HCA terminated the case because it could not establish that the fee increase was part of a strategy aimed at creating a long-term, non-transitory price structure with zero margin, and that the change in opening hours led to a competitive disadvantage for competitors.

In the Groupama case, ${ }^{88}$ the HCA investigated liability insurance of real estate professionals. On the one hand, the HCA alleged that the agreement, between the insurer and the Hungarian Real Estate Association on the mandatory nature of liability insurance and the applicable fee, qualified as an anticompetitive agreement. On the other hand, the HCA alleged that the insurer provided discounts to the Hungarian Real Estate Association, which hindered market entry and created disadvantageous conditions for competitors. The HCA terminated the case because the dominant position of the insurer was not proven and particularly, because the market was contestable and there were non-restrictive termination options of the agreement between the insurer and the Hungarian Real Estate Association.

The HCA opened proceedings against Budapest Airport ${ }^{89}$ because the company offered less favourable conditions to independent taxi companies, relating to the boarding of passengers at the area of the airport, compared to the conditions applied to contracted taxi companies. The HCA concluded that the investigation could not show sufficient evidence to substantiate that the discriminatory conduct applied by the dominant company created a disadvantageous competitive environment that resulted in consumer harm. As a result, the proceedings were terminated by the HCA.

In the Sanofi case, ${ }^{90}$ the HCA investigated whether the company has placed certain groups of pharmaceutical wholesalers in a disadvantageous market position in comparison to incumbent wholesalers by refusing to contract with them. The HCA suspected that the pharmaceutical manufacturer did not select its wholesale partners based on an assessment of the anticipated and actual economic gains resulting from the business relation. However, based on data gathered during the proceeding, there was no clear evidence that the conduct of the investigated undertaking could have resulted in significant adverse consequences for consumers, thus, the HCA terminated the proceeding.

In the $R T L$ case, ${ }^{91}$ the HCA alleged that the TV company, by offering two of its channels to advertisers in a package for a so-called common channel average price, foreclosed competitors from the national television advertising market. The HCA found that although the turnover-based market share was high, its main competitor seems to have a higher market share calculated based

\footnotetext{
88 Case No. Vj-19/2011.

89 Case No. Vj-95/2011.

${ }^{90}$ Case No. Vj-61/2014.

91 Case No. Vj-49/2015.
} 
on other factors (such as audience share). The HCA took into consideration that the main competitor of the TV company expanded its portfolio, thus, the existence of a permanent dominant position of the TV company was unlikely. Although the HCA did not examine the abusive nature of the TV company's practices, the HCA noted that the recent decrease in market power indicates the absence of foreclosing practices.

\section{Cost allocation in dominance cases}

Cost allocation is the most important part of economic analyses proving price related abuse cases and it affects both exploitative and exclusionary conducts. In excessive pricing investigations, the question arises whether prices are significantly above a competitive benchmark, where this benchmark is often estimated based on the relevant costs of the dominant company (plus a reasonable margin). In exclusionary cases, authorities investigate whether the prices of the dominant company are below its own costs, which eventually also boils down to a cost allocation exercise (that is, which costs of the dominant company should be considered).

\section{Exploitative (excessive pricing) cases}

In exploitative cases, price is considered unfairly high if the cost of production (or providing a service) plus the expected 'fair' profit 92 is below the selling price. The HCA investigates unfair prices either (i) by analysing individual cost elements and an estimation of the 'fair' profit or (ii) by benchmarking the potentially anticompetitive prices with prices of comparable products or services. This is in line with the European case-law set out in United Brands. ${ }^{93}$ The test for excessive pricing in United Brands has two limbs: (i) whether the costs incurred are significantly lower than the prices charged; (ii) whether the prices charged are unfair in themselves or in comparison to prices of competing products or services. Both limbs must be investigated. ${ }^{94}$

\footnotetext{
92 Adjusted for market risks.

93 Judgment of the Court of 14 February 1978. - United Brands Company and United Brands Continentaal BV v Commission of the European Communities. - Chiquita Bananas. - Case 27/76.

94 Note that the HCA explicitly said that an investigation based on an economic value (fair profit) is only applicable if carrying out a benchmark analysis is not possible ( $\mathrm{Vj}-33 / 2004$, para. 56 and Tóth, A., 2008).
} 
The HCA did its homework and carried out an analysis based on both, a costprice as well as a comparison approach in their excessive pricing investigation against Északdunántúli Vízmű (North Transdanubian Waterworks, NTW), a regional water supplier. ${ }^{95}$ This investigation contained many elements of an excessive pricing case, so we discuss it in detail.

The investigation was concerned with services offered by NTW related to the testing and verifying ancillary water meters and their periodic certification costs. First, NTW was found dominant (being the sole supplier) in the regional market of periodic certification. Then the HCA calculated that the average margin of NTW was $19-24 \%$. The authority claimed that such margins were too high in the market. ${ }^{96}$

The HCA applied a benchmark analysis to test whether NTW's costs and prices were justified. A benchmark analysis should identify sufficiently comparable products and services and ensure that the costs of these comparable products and services are incurred in a competitive environment (otherwise one may compare two inefficient firms). The HCA recognized these issues yet accepted that the costs of single suppliers in other territories of Hungary (namely suppliers that were in themselves dominant in their respective local markets) are appropriate to consider in a benchmark analysis. ${ }^{97}$ The HCA assumed that the services provided (ancillary water meter testing and verification) have homogeneous cost-elements and if some providers face higher costs stemming from the idiosyncratic characteristics of the local market, these should be proven by the companies themselves. ${ }^{98}$

Furthermore, based on NTW and publicly available data, the HCA estimated the level of economically justified costs and concluded that only approx. 50\% of the costs incurred according to NTW were justified, so only these costs should be included in the margin calculations. ${ }^{99}$ This is an interesting point of the investigation, which implies that the HCA either did not believe that the cost breakdown of the dominant company was correct, or punished a dominant company for being inefficient.

In $N T W$, the interpretation of economically justified costs also seems narrow-minded (this is a weakness of other excessive pricing cases of the

95 Case No. Vj/43/2013.

96 Ibidem, para. 138. Comparable companies have close to zero margins related to the services investigated (para. 187.).

97 Ibidem, para. 77-80. A simple correlation analysis between prices/costs and local market characteristics (size of settlements served, population size, etc.) revealed no statistical relationship. Hence, the HCA assumed that local market characteristics do not affect service costs. Hence, costs of companies from different local markets in Hungary are comparable (para 86).

98 Ibidem, para. 86.

99 Ibidem, para. 135. 
HCA as well, see below). The differentiation between: (i) the costs appearing in the books of the dominant company, and (ii) economically justified costs based on the (often subjective) view of the investigating authority, originates from the case-law of the European Commission (EC) in e.g. Scandlines and Sundbusserne. ${ }^{100}$ In these cases, the EC rather focuses on the economic value of services and attempts to derive the costs actually incurred based on the economic value of the products or services. The economic value, however, is not an exact figure. For example, in Scandlines, the EC states that the economic value should be determined based on the circumstances of the case including non-cost factors (like demand for the product or service). ${ }^{101}$ The economic value is not connected to the cost of production only, but it is highly dependent on the buyers' willingness to pay and other characteristics of the competitive environment. In turn, this could make proving an excessive pricing case extremely difficult (see also Győrfi, 2016, p. 35-36). Bodócsi (2009, p. 31) also noted that separating costs into economically justified and unjustified parts can generate problems.

The question of economically justified costs arose in Magyar Posta $I I^{102}$ as well. In this case the HCA investigated whether prices charged by the incumbent Hungarian postal operator on PO Box rental services were excessive or discriminative (the HCA did not find evidence for any of these). The HCA was unable to carry out a benchmark analysis lacking comparable products in the market and so they decided to carry out a cost-base analysis. However, the HCA did not accept the cost allocation of Magyar Posta and the HCA itself estimated the costs related to PO Box rental services. Eventually, the uncertainties surrounding the cost estimation ${ }^{103}$ resulted in the HCA not relying heavily on these estimates. For reasons set out above, we believe that the HCA's approach to estimate economic value solely based on costs, disregarding non-cost factors, was also incomplete in Magyar Posta II.

In any case, even if the authority concentrates on costs, the difficulty in proving unlawful excessive pricing is illustrated by the instances of two similar investigations. ${ }^{104}$ In both cases, the HCA decided not to rule on them conclusively, because it was extremely difficult to allocate business costs. ${ }^{105} \mathrm{In}$ UPC II, the HCA revealed that $40 \%$ of UPC's income was originated from

100 Case COMP/A.36.568/D3 - Scandlines Sverige AB v Port of Helsingborg; Case COMP/A.36.570/D3 - Sundbusserne v Port of Helsingborg. The HCA itself referred to these decisions.

101 Case COMP/A.36.568/D3 - Scandlines Sverige AB v Port of Helsingborg, para. 232.

102 Case No. Vj/57/2013.

103 Ibidem, para. 243-244.

104 UPC II (Vj-23/2007), FiberNet (Vj-4/2006).

105 That the optimal allocation of costs to products or services is a difficult task see Infrapont (2007) and Győrfi (2016). 
non-cable television businesses, which made it impossible to substantiate a cost-based analysis that would have sufficiently proven the presence or absence of an anti-competitive practice. 106

Finally, the issue of allocating indirect costs to the products or services affected by the abuse also came up in Antenna Hungária. ${ }^{107}$ In this case, the HCA attempted to estimate the economic value of terrestrial and satellite television services based on economically justified costs. In its decision, the HCA clarified that the allocation of indirect costs (that is, costs that cannot be directly allocated to the services offered) is a burdensome exercise and, upon suspecting an infringement, the authority is obliged to prove that their own allocation of indirect costs is the only possible allocation and all other allocations are unjustified. According to Infrapont (2007, p. 31), it is almost impossible to prove that certain types of costs are economically unjustified. Hence, the HCA has not left much room for manoeuvre.

In this section, we demonstrated that the analysis of excessive pricing requires a thorough cost-estimation by the authority which, in many circumstances, can be extremely difficult. Also, the concept of economic value as applied by the HCA should be expanded by accounting for non-cost factors that may also affect (non-abusive) prices. In the following section, we discuss the issue of cost-allocation in the framework of exclusionary (foreclosure) cases.

\section{Exclusionary (foreclosure) cases}

The question of allocating costs arises in anti-competitive foreclosure cases as well (exclusionary practices). Authorities investigate whether a competitor as efficient as the dominant company, facing the prices set by the dominant company, can supply the market. The main issues are: (i) what costs of the dominant company should be accounted for, and (ii) whether these costs are below the prices applied. In this section, we investigate the cost allocation practice and the application of price-cost tests by the HCA. Our research revealed that the analyses carried out by the HCA were in line with the general practice applied by the EC in foreclosure cases.

In foreclosure cases, the relevant cost measures are at the forefront of an antitrust analysis. In an earlier case, the HCA held that pricing below average total costs (ATC) and above average variable costs (AVC) is, in general, not problematic (they applied the AKZO-test ${ }^{108}$ ). In a later investigation, the

\footnotetext{
106 Case No. Vj-23/2007, para. 25.

107 Case No. Vj-27/2005.

108 See in CJEU judgment of 3 July 1991, Case 62/86, AKZO Chemie BV v Commission, European Court reports 1991, page I-03359.
} 
HCA used instead the benchmark of average avoidable costs (AAC) rather than of AVC. This latter approach is in line with the Guidance of the EC. 109

The AKZO-test was applied by the HCA in the antitrust investigation against incumbent cable provider in T-Kábel. ${ }^{110} \mathrm{~T}$-Kábel was suspected of applying anti-competitive discounts in certain parts of Budapest, where it faced competition from a smaller competitor, RubiCom. The HCA concluded that T-Kábel prices were between AVC and ATC. Below ATC pricing, in general, is not problematic but it can be anti-competitive if there is an intent to foreclose competitors. The HCA found no evidence for such foreclosing intent (the discounts applied by T-Kábel were a temporary reaction to the local market entry of RubiCom) ${ }^{111}$, so the case was ultimately closed without a public intervention.

Later on, the HCA applied the AAC benchmark (instead of AVC) in the foreclosure case of Magyar Posta. ${ }^{112}$ The incumbent postal service provider Magyar Posta was accused, by competitors, of cross-subsidizing revenues from the universal postal service market (where Magyar Posta was the sole service provider) to the competitive unaddressed advertising mail services market. The HCA found that Magyar Posta did not breach competition as average prices remained between AAC and ATC. ${ }^{113}$ As mentioned above, below ATC pricing could have been anti-competitive, had there been an intent of foreclosure by Magyar Posta (such intent was not identified by the HCA). ${ }^{114}$ Some complainants pointed out that for some key customers the applied prices were below AAC, and so it was anti-competitive. But the HCA correctly assessed that for individual customers $\mathrm{AAC}$ is equivalent to average variable costs (AVC) because, considering individual agreements, only variable costs are avoidable. ${ }^{115}$ Prices, however, were never below AVC. The HCA correctly concluded that prices above AAC but below ATC are justified in the market of unaddressed advertising mail services because, had Magyar Posta ceased such services, costs would have decreased less than revenues. The HCA also stated that cross-subsidising does not take place in the context of competition law if prices are above AAC. ${ }^{116}$

109 AAC is favoured by economists as it includes all variable and fixed costs that can be avoided if production of the products in question ceases.

110 Case No. Vj-88/2007.

111 Ibidem, para. 62.

112 Case No. Vj-32/2012.

113 AAC included costs incurred during (i) the delivery of advertisement material (variable costs) and (ii) the collection and processing of advertisement material (avoidable fixed costs) (Vj/32/2012, para. 42-43).

114 Ibidem, para. 111.

115 Ibidem, para. 114 and 115.

116 Ibidem, para. 116. 
Finally, in $M O L, 117$ the HCA investigated the potentially exclusive nature of MOL's business practices vis-à-vis their competitors. The HCA carried out an 'as efficient competitor' test by investigating first the difference between: (i) MOL's wholesale prices charged to vertically integrated oil companies and (ii) the retail costs of MOL; and second, the difference between (a) MOL's wholesale prices charged to large oil (downstream) retailers and (b) the retail costs of MOL. After a lengthy cost allocation exercise, the HCA did not find an indication for margin squeeze. The HCA also investigated the discounting system of MOL and concluded that MOL did not discriminate anti-competitively between their customers. There were therefore no issues identified by the HCA concerning the profit margins of MOL. The only problem the HCA identified was related to MOL's list prices. The HCA revealed that prices reacted more quickly to increases in stock market prices than to drops ('rocket and feather effect'). This is only indirectly related to costs, through the volatility of the financial markets, but shows a vigilant approach of the HCA to relatively concentrated markets where such price cycles may emerge.

\section{Significant market power of retailers}

Finally, our paper examines the issues related to significant market power. Significant market power regulations were originally introduced in the EU to prevent a restriction of competition by major suppliers on telecommunication markets. Such regulations imposed ex ante behavioural requirements, which were applicable from a lower market share threshold (25\%) than the market share threshold for dominance. The purpose of these regulations was to create a level playing field (Tóth, 2016, p. 58). The SMP rules in network markets are enforced by sectorial regulatory bodies. The HCA's competency, however, extends to a different type of 'significant market power' where the anti-competitive conduct of dominant firms arises in the context of the purchasing behaviour of retailers. According to the relevant legislation, a company has significant market power in a downstream market if the retailer is an unavoidable trading partner to suppliers and, due to its high market share as a purchaser, it can influence market access conditions regionally or nationally. The concept of significant market power is, in fact, not part of the Competition Act, but is regulated by the Trade Act ${ }^{118}$ that prohibits the

\footnotetext{
117 Case No. Vj/50/2010.

118 Act CLXIV of 2005 on Trade.
} 
abuse of this market power vis-à-vis supplier. ${ }^{119}$ Cases based on significant market power are not opened frequently by the HCA. We are aware of only two prohibition decisions. ${ }^{120}$

\section{Regulatory background}

The Trade Act explicitly prohibits the abuse of significant market power by retailers. Section 7 (3) of the Trade Act quantifies significant market power in nominal terms. Significant market power is assumed if the company group turnover was at least HUF 100 billion [EUR 290 million] in the previous calendar year. The special treatment of large retailers probably stems from the implicit objective of the lawmakers to protect smaller suppliers, but a turnover-based definition is at odds with competition theories underlying market dominance. A retailer - not meeting the turnover threshold - may also be deemed to have significant market power if it holds one-sidedly a stronger bargaining position vis-à-vis a supplier, either due to the existing market structure, restrictions on entering the market, the company's market share, financial strength and other resources, or the magnitude of the company's commercial network, the size and location of its commercial establishments.

A detailed list of prohibited practices is provided by Section 7 (2) the Trade Act. Amongst others, a retailer with significant market power is not allowed to (i) apply undue discrimination, (ii) restrict access to market channels, (iii) charge for services serving only the retailer's interests, (iv) unjustifiably amend contractual conditions to the detriment of the supplier, (iv) charge for listing, stocking, (v) sell below purchasing prices. The reason for increased protection levels provided to suppliers is mainly due to the presumed asymmetric position and negotiating power of the parties, and that such unfair practices could likely lead to detrimental consequences for the suppliers. It should also be noted that the relevant products are mainly daily consumer products, so these measures aim to protect the general interests of the consumer as well (by ensuring a high level of product choices).

In the case of an infringement of the above rules by a retailer holding significant market power, the HCA is entitled to initiate proceedings based on the Competition Act. Interestingly, Section 7/A of the Trade Act also provides for a dominance test in nominal terms: any retailer whose turnover realised in the previous financial year exceeds HUF 100 billion [EUR 290 million]

119 Not to be confused with Hungarian ex ante SMP rules: Act XL of 2008 on natural gas; Act LXXXVI of 2007 on electric energy and Act CLXXXV of 2010 on media services and on the mass media.

120 Spar (Vj-47/2010), Auchan (Vj-60/2012). 
generated from food retail is automatically deemed to be in a dominant position. Apart from the fact that this antitrust rule is misplaced in the Trade Act, it has significant deficiencies compared to the traditional dominance test: the turnover threshold is set randomly, the question of dominance is thereby not in the discretion of the HCA but automatic, and the test disregards all market circumstances (for example, it precludes the HCA from assessing the level of competition in the retail market).

It must be mentioned that in the case of food retail, abuses are not regulated by the Trade Act. A separate act ${ }^{121}$ - not even requiring the existence of buyer power - contains a more elaborate list of problematic retailer practices. The enforcement of this act is not in the jurisdiction of the HCA.

\section{Case-law}

Before imposing the first fine, the HCA conducted several investigations that were either terminated without the finding of an infringement ${ }^{122}$ or with commitments. ${ }^{123}$ Based on the first cases, concerns were raised that the legislator's intent behind the SMP rules of the Trade Act disregarded modern commercial practices, and that there is not always an asymmetry in the bargaining power of suppliers and retailers, namely there is no abuse (Szathmáry and Zubriczky, 2009, p. 37).

The first fine imposed for the infringement of Section 7 of the Trade Act was in the SPAR case. ${ }^{124}$ SPAR applied a performance-based bonus system with a fixed and a dynamic part. The HCA found that the application of the bonus qualified as the prescription of unjustified conditions. The HCA collected numerous documentary evidence on business negotiations between the retailer and the suppliers, which corroborated that SPAR applied the bonus system unilaterally. The HCA established that the fixed part of the bonus was not introduced with the objective to compensate additional services provided by the retailer and, therefore, could not be considered as justified. The dynamic part of the bonus was considered as unjustified because it had to be paid even if the retailer failed to reach the target sales (that were set as the condition for the bonuses). The decision was confirmed in judicial review. ${ }^{125}$

121 Act XCV of 2009 on the prohibition of unfair retailer practices towards suppliers in case of agricultural or food products.

122 Case No. Vj-149/2007.

123 For example, case No. Vj-92/2006 (the first SMP case), Vj-23/2008, Vj-91/2008, Vj-92/2008, Vj-93/2008, Vj-94/2008.

124 Case No. Vj-47/2010.

125 Judgment of the Curia - Kfv.III.37.392/2015/5 (29 September 2015). 
Not long after the SPAR case, the HCA initiated another investigation against Auchan. ${ }^{126}$ In that case, the application of a so-called subsequent price discount subsidy was investigated. The HCA applied the same assessment: establishing unilateral nature based on contract negotiations and determining the unjustified nature based on conditions the retailer had to meet to be entitled to the payment. The HCA found that the application of the subsidy qualified as a unilaterally charged fee (for listing of products). ${ }^{127}$ The decision was confirmed in judicial review. ${ }^{128}$

\section{Conclusions}

Notwithstanding that we observe a significant decrease in the number of abuse of dominance cases pursued by the HCA recently, we do not think that it necessarily means weaker law enforcement. Although there are some features we are unable to observe (for example, whether large companies have increased compliance with competition law, or the authority has now fewer resources to pursue dominance cases), our research revealed that the HCA's dominance investigations, over time, became more aligned with the legal and economic principles of the EC. ${ }^{129}$ This led to a higher level of legal certainty.

In connection with the exclusionary case-law of the HCA, there is a pattern of decreasing enforcement. The last prohibition decision was adopted more than four years ago, the one before that nine years ago. We identified three reasons for reduced enforcement: (i) a preference to close cases with a commitment, (ii) termination of cases because of insufficient evidence, and (iii) earlier cases were related to markets that are less important now (fixed-line telephony) or to markets where the transition to market economy caused issues (energy, railway, transport). Furthermore, whereas the early case-law did not rely on EU guidance, more recently the HCA started referencing EU case-law. This resulted in the creation of some genuine tests (most prominently, the margin squeeze test) combined with detailed fee/cost calculations and comparisons.

126 Case No. Vj-60/2012.

127 The HCA decision was first annulled in judicial review, however, in the final judgment, the decision was approved.

128 Judgment of the Metropolitan Tribunal - 12.Kf.650.017/2019/9 (27 March 2019).

129 This tendency is also reflected by the content of the Position statements of the HCA (available at https://bit.ly/2O7CSiO, only in Hungarian). The Position statements do not legally bind the authority, but they serve as guidelines for market players about the practical implementation of the Competition Act by the HCA. 
The arguments put forward by the HCA in excessive pricing cases have also increased in quality over time. Whereas in the early 2000s, the HCA often investigated pricing practices with a narrow-minded interpretation of the market circumstances (for example, comparing price increases with inflation), more recent cases show a refined approach that is also in line with mainstream economic thinking. The only suggestion we may have is that the concept of economic value needs to be revised or complemented in future dominance cases.

Stronger criticism can only be formulated about the legislation surrounding large retailers, as we find the concept of significant market power problematic. This is mainly due to the confusion of regimes. The sales value-based threshold, that categorizes retailers as dominant or non-dominant, lacks flexibility (otherwise inherent in competition law) when addressing the question of market power through comprehensive market investigations. The original concept of separate (non-competition) rules to address market power in retail was distorted by the adoption of an unfounded food retail dominance test, and a separate food retail regime not requiring market power at all. There also seems to be confusion in the case-law in terms of the legal test applied to rebates offered to suppliers in the form of subsidies. In one case the HCA punished the unfair nature of the business conduct, in another case it was the unilateral application of subsidies that the HCA identified as anti-competitive. Hence, it is unclear which of these two should be addressed by competition law compliance in a retail context.

\section{Literature}

Bodócsi, A. (2009). Az árak versenyhatósági ellenőrzésének kérdőjelei, Versenytükör, V. évf. 2. sz., 2009 június, p. 29-34. Retrieved from: https://bit.ly/3f1bYFl (29.04.2020).

Communication from the Commission - Guidance on the Commission's enforcement priorities in applying Article 82 of the EC Treaty to abusive exclusionary conduct by dominant undertakings (Text with EEA relevance), OJ C 45, 24.2.2009, p. 7-20.

Cserny, Á., Téglási, A. (2015). A gazdasági alkotmányosság új fejezete Magyarországon - Az Alkotmánybíróság a korábbi alkotmányos alapelvek fogságában, Jog - Állam Politika, 7. évf. 1. sz. / 2015 p. 7-25. Retrieved from: https://bit.ly/2Th0oNf (15.05.2020).

De Coninck, R. (2018). Excessive Prices: An overview of EU and national case-law, e-Competition Bulletin, Excessive Prices, Art. No 86604, 21 Jun 2018.

Győrfi, A. (2016). A Túlzó Árazás Mint Erőfölénnyel Való Visszaélés az Uniós és a Magyar Joggyakorlatban, Verseny és Szabályozás, 2016. Évf., p. 33-66. Retreived from https:// bit.ly/2WgaZIO (02.05.2020).

Infrapont (2007). A túlzó árazás kezelése és módszertani megközelítése a versenyhatósági gyakorlatban. Retrieved from https://bit.ly/3aKrYs4 (29.04.2020). 
Juhász, M., Ruszthyné Juhász, D., Tóth, A. (2014). Kommentár a tisztességtelen piaci magatartás és a versenykorlátozás tilalmáról szóló 1996. évi LVII. törvényhez. Budapest: Gazdasági Versenyhivatal.

Motta, M. (2009). Competition Policy, Theory and Practice. New York: Cambridge University Press.

Nagy, Cs. (2013). A Chicago-School Island in the Ordo-liberal Sea? The Hungarian Competition Office's Relaxed Treatment of Abuse of Dominance Cases. Yearbook of Antitrust and Regulatory Studies, 6(8), p. 53-74.

OECD Policy Roundtables, Directorate for Financial and Enterprise Affairs, Competition Committee, Excessive Prices, DAF/COMP(2011)18, 07-Feb-2012.

Szathmáry, J., Zubriczky, B. (2009). A kereskedelmi törvény alkalmazása során szerzett tapasztalatok. Versenytükör, V. évf. 2. sz., 2009 június, p. 35-40. Retrieved from https:// bit.ly/2Tj9bht (15.05.2020).

Szilágyi, P. and Tóth, T. (2013). Recent Competition Policy Developments in Hungary Unfair Commercial Practices, Cartels and Abuse of Dominance. Yearbook of Antitrust and Regulatory Studies, 6(8), p. 173-190.

Tóth, A. (2008). A Gazdasági Versenyhivatal túlzó ár megállapításával kapcsolatos gyakorlata, Gazdaság és Jog, HVG-Orac, 16. évf., 2008/6., pp 3-8.

Tóth, A. (2016). Versenyjog és határterületei - A versenyszabályozás jogági kapcsolatai. Budapest: HVG-ORAC.

Tóth, T. (2014). Az Európai Unió versenyjoga. Budapest: Complex.

Tóth, T. (2008). A Gazdasági Versenyhivatal gyakorlata a fogyasztók megtévesztése és gazdasági erőfölénnyel való visszaélés területén. Acta Conventus de Iure Civili, 2008 (9), p. 9-20. Retrieved from https://bit.ly/2TkEcBQ (15.05.2020).

Valentiny, P. (2004). Árprés és felfaló árazás - Közgazdasági elmélet, bírói, szabályozói gyakorlat. Közgazdasági Szemle, LI. évf., 2004. január, p. 24-45. Retrieved from https:// bit.ly/2WElhE2 (15.05.2020). 